\title{
RISK ASSESSMENT FOR COMPOUNDING OINTMENTS QUALITY BY ISHIKAWA DIAGRAM CONSTRUCTION
}

\author{
LESIA SAVCHENKO $^{1 *}$, YURI PIDPRUZHNYKOV ${ }^{2}$, LIUDAS IVANAUSKAS $^{3}$, AUDRIUS $^{2}$ \\ LUKOŠIUS $^{4}$, VICTORIYA GEORGIYANTS ${ }^{5}$
}

\author{
${ }^{1}$ Department of Quality, Standardization and Certification of Medicines, Institute of Pharmacy Professionals Qualification \\ Improvement, National University of Pharmacy, 17 Zahysnynykiv Ukrainy Square, 61001, Kharkiv, Ukraine \\ ${ }^{2}$ Department of Quality Management, National University of Pharmacy, 4 Valentynivska Street, 61000, Kharkiv, Ukraine \\ ${ }^{3}$ Department of Analytical and Toxicological Chemistry, Lithuanian University of Health Sciences, 9 A. Mickevičiaus Street, \\ 44307, Kaunas, Lithuania \\ ${ }^{4}$ Department of Pharmacognosy, Lithuanian University of Health Sciences, 9 A. Mickevičiaus Street, 44307, Kaunas, \\ Lithuania \\ ${ }^{5}$ Department of Pharmaceutical Chemistry, National University of Pharmacy, 4 Valentynivska Street, 61000, Kharkiv, \\ Ukraine
}

*corresponding author: savchenkolesia@gmail.com

\begin{abstract}
To date compounding medicines don't need to pass the state registration process in any country. In order to ensure their quality, the introduction of a pharmaceutical quality system with risk assessment process is recommended in most countries worldwide. This research identifies the risks for quality of compounding ointments by Ishikawa diagram construction. Six major categories of risks (personnel; active pharmaceutical ingredients (API) and excipients; equipment and facilities; preparation technology; stability; quality control) were defined. Factors recommended to be monitored and specific risk factors for this dosage form quality were also identified. Their compliance and control will allow pharmacies to produce constantly ointments with appropriate quality and to prevent harm to the patient from administration of dosage forms with a lower quality. The similarity of the regulatory framework requirements for the preparation and quality control of the compounding ointments allows using the obtained results to ensure their quality in different countries.
\end{abstract}

\section{Rezumat}

Până în prezent, medicamentele magistrale nu se supun înregistrării în nici o țară. De aceea se recomandă introducerea unui sistem de asigurare a calității și a unui proces de evaluare a riscurilor. Prezentul studiu identifică riscurile pentru calitatea unguentelor preparate în farmacie, cu ajutorul diagramei Ishikawa. Au fost definite şase categorii majore de riscuri (personal; ingrediente farmaceutice active și excipienți; echipamente şi instalații; tehnologia de preparare; stabilitate; control al calității). Au fost identificați factorii ce se recomandă a fi monitorizați, alături de factorii de risc specifici, pentru această formă farmaceutică. Conformitatea și controlul acestora vor permite farmaciilor să producă în mod constant unguente cu o calitate adecvată, care să prevină posibilele reacții în urma administrării unei forme dozate cu o calitate necorespunzătoare. Similitudinea cerințelor autorităților de reglementare pentru prepararea și controlul calității unguentelor permite utilizarea rezultatelor obținute în acest studiu pentru a asigura calitatea acestora în diferite țări.

Keywords: risk management, Ishikawa diagram, ointments, pharmaceutical compounding

\section{Introduction}

One of the differences between compounding preparations and industrially produced medicines is the absence of the marketing authorization for the first ones. However, this fact does not release them from the necessity to meet the established requirements for quality, efficiency, and safety. This issue is widely discussed in both Ukraine and the European Union (EU), and the USA [1-5, 16, 18-20]. Requirements for quality of pharmaceutical products in Ukraine are regulated, first, by the State Pharmacopoeia of Ukraine (SPhU) [11, 12], as well as guidelines [13, 14] and the orders of the Ministry of Health of Ukraine (MOHU)
[15]. Compared to the requirements of the European Pharmacopoeia (EurPh) [8], the SPhU contains broader requirements for compounding medicines preparation and quality control of them $[11,12]$. However, general requirements that are outlined in the general monograph "Pharmaceutical preparations" are identical $[8,11]$. The main requirements of the monograph are the implementation of a proper pharmaceutical quality system for the preparation of medicines in a pharmacy. Similar requirement contains the Order of MOHU [15]. According to these requirements, the main task of the business entity engaged in the preparation of medicines in pharmacies is the quality system implementation. It should include precautionary measures, quality control, 
requirements for employees, facilities and equipment, documentation, active ingredients and excipients, packaging, technological process. In the USA [17], the necessity of introducing the pharmaceutical quality system for compounding medicines preparation it is governed by the requirements of the articles 795 "Pharmaceutical compounding - nonsterile preparations", 797 "Pharmaceutical compounding - sterile preparations" and 1163 "Quality assurance in pharmaceutical compounding" of the United States Pharmacopoeia (USP). Thus, the proper level of compounding medicines quality, as well as industrial production medicines, in Ukraine, EU and the USA is ensured by the implementation of an effective quality management system.

Recommendations for the implementation of this system contains the guideline Q10 on pharmaceutical quality system of the International Council for Harmonization of Technical Requirements for Pharmaceuticals for Human Use (ICH) [6]. According to its requirements, one of the important components of an effective quality system is the risk management for quality. The quality system implementation guarantees to enterprise the achievement of the main three goals: suitable product quality, establishment and maintenance of a controlled condition and promotion of continuous improvement [6]. The achievement of the last two goals is facilitated by the application of the risk management process for quality. Mandatory assessment of the risk for quality during medicines preparation in pharmacies is governed by the requirements of the division "Ethical considerations and guidance in the preparation of unlicensed pharmaceutical preparations" of the monograph "Pharmaceutical preparations" [8, 11]. It emphasizes that this process is especially important for the compounding (unlicensed) medicines that are not subject to the state registration.

The assessment process of risk for quality in the pharmaceutical field is regulated by ICH guideline Q9 on quality risk management [7]. According to its recommendations, the first step in this process is the risk identification. It is related with the question "what could have gone wrong within the analyzed process that can lead to the defect of quality?", when determining the list of key aspects, processes or factors that may adversely affect the quality of the finished product if something goes wrong.

There are some publications where the need for implementation and approaches to the development of a quality assurance system for the preparation of medicines in pharmacies have been described [1-5, 16, 18-20]. However, they are too generalised. There are no directional studies on the factors that can negatively influence the quality of compounding ointments, which undoubtedly have their own specificity. Thus, the purpose of our study was the identification of the risks for the quality of compounding ointments. It is the basis for further steps in the quality risk management process, in particular for their quantitative evaluation, and will allow to identify critical factors for quality of compounding ointments.

\section{Materials and Methods}

The materials of the research were the regulatory framework of Ukraine, EU and the USA on the preparation rules and requirements for quality control of the compounding ointments. For the risk identification, general risk assessment methods B.1 "Method of brainstorming" and B.17 "Analyzing of cause and effect relationships" (the Ishikawa diagram) (according to the IEC/ISO 31010:2019 guideline [9]) were used. The methods of systematic, structural-logical analysis and the bibliosemantic method were also used in this study.

\section{Results and Discussion}

According to the IEC/ISO 31010:2019 guideline requirements, the majority of the methods listed in Annex A can be used for risk identification [9]. However, the most successful qualitative visual method which was widely used for this purpose is the causeand-effect analysis method (more often it is called fishbone diagram or Ishikawa diagram). It allows to identify the possible causes of unwanted events and to group them into main categories. The most simple and common version of this diagram includes six main categories: man, material, method, measurement, machine, and mother nature [10].

Since our goal was the identification of the risk for the compounding ointments quality, this formulation became the head of the diagram for which major categories that could cause it with subsequent identification of the reasons for each of them were defined.

In the process of risks identification for the quality of compounding ointments, all possible steps of the preparation process, requirements for the quality control, approaches to selection of storage conditions and shelflives, packaging conditions and application opportunities of ointments were analysed. The identified risks were conditionally divided into several major groups (risks for the patient) (Figure 1).

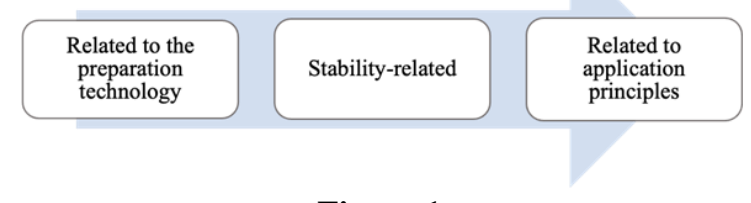

Figure 1.

The main risk groups for the quality of compounding ointments which affect the consumer

To identify the risks for quality of the compounding ointments, the following documents were also analysed: 
general monograph "Pharmaceutical preparations" of the $\mathrm{SPhU}$ and EurPh [8, 11]; general monograph "Nonsterile compounding medicines" of the SPhU [12]; general article "Semisolid compounding medicines" of the SPhU [12]; general article "Semi-solid preparations for cutaneous application" of the SPhU and EurPh [8, 11]; general article "Nasal preparations" of the SPhU and EurPh $[8,11]$; general article "Eye preparations" of the SPhU and EurPh $[8,11]$; general article "Vaginal preparations" of the SPhU and EurPh [8, 11]; general article 795 "Pharmaceutical compounding - nonsterile preparations" of the USP [17]; general article 797 "Pharmaceutical compounding - sterile preparations" of the USP [17]; general article 1163 "Quality assurance in pharmaceutical compounding" of the USP [17]; the Order of the Ministry of Health of Ukraine № 812 from October 17, 2012 "On approval of the rules of manufacturing (preparation) of medicines in the conditions of pharmacies" [15]; Guideline ST-N of the Ministry of Health of Ukraine 42-4.5:2015 "Requirements for the preparation of non-sterile medicines in pharmacies" [13]; Guideline ST-N of the Ministry of Health of Ukraine 42-4.6:2015 "Requirements for the preparation of sterile medicines in pharmacies" [14].

The analysis has identified six major categories that can affect the quality of semisolid compounding dosage form: personnel, API and excipients, equipment and facilities, preparation technology, stability and quality control.
For each of the selected categories, reasons that should be considered to reduce the risk for quality of compounding ointments were defined. By the results of the research, the Ishikawa diagram was constructed (Figure 2). It shows six selected categories and their related factors.

Personnel. First of all, the quality of compounding ointments depends on the personnel involved in the preparation process. The first risk factor in this category is the proficiency level of the staff. The experience of the staff involved in the preparation, the availability of appropriate education and the timely completion of appropriate training with continually expanding of their compounding knowledge are important in this context. According to the requirements [15, 17], medicines should be prepared by employees with special education and who meet the unified qualification requirements.

The head of the entity must ensure that employees are constantly trained in accordance with legislation. Before preparing any dosage form, the pharmacist checks the formulation of the prescription; correctness of prescription and compatibility of its ingredients; doses of API; calculates the amount of API and excipients; in some cases, selects the ointment basis. There are different sources of risk for quality of compounding ointments associated with all pharmacist activities (Table I).

Table I

Potential sources of staff-related risks for quality of compounding ointments

\begin{tabular}{|c|c|c|}
\hline $\begin{array}{l}\text { Potential sources of quality } \\
\text { defects }\end{array}$ & The consequence of the potential defect & Proposed actions for risk mitigation \\
\hline $\begin{array}{l}\text { Errors in the calculation of } \\
\text { the dose of API or excipients }\end{array}$ & $\begin{array}{l}\text { Insufficient pharmacological effect or overdose } \\
\text { during ointment dosage application }\end{array}$ & $\begin{array}{l}\text { Verification of calculation before dosage } \\
\text { form preparation by the responsible person }\end{array}$ \\
\hline $\begin{array}{l}\text { Preparation of ointments with } \\
\text { incompatible components }\end{array}$ & $\begin{array}{l}\text { Release of inappropriate physical properties; the } \\
\text { appearance of impurities or the loss of uniformity } \\
\text { of the dosage form during storage; loss of } \\
\text { consumer properties of ointment, patient's refusal } \\
\text { to purchase such dosage form }\end{array}$ & $\begin{array}{l}\text { Checking of the prescription for } \\
\text { incompatible ingredients before dosage } \\
\text { form preparation. Manufacturing under } \\
\text { the supervision of the responsible person. }\end{array}$ \\
\hline $\begin{array}{l}\text { Wrong choice of ointment } \\
\text { base }\end{array}$ & $\begin{array}{l}\text { Delamination of ointment both immediately and } \\
\text { during storage period; violation of uniformity of } \\
\text { API dosage; uneven application of ointment } \\
\text { during using; harm to the patient's health; loss of } \\
\text { consumer properties of the ointment, patient's } \\
\text { refusal to purchase such dosage form }\end{array}$ & $\begin{array}{l}\text { Verification of ingredients selection by the } \\
\text { responsible person }\end{array}$ \\
\hline $\begin{array}{l}\text { Choosing the wrong ratio of } \\
\text { base and liquid components }\end{array}$ & $\begin{array}{l}\text { Delamination and loss of consumer properties } \\
\text { (separation of excess liquid) with subsequent loss } \\
\text { of uniformity of ointment API dosage; uneven } \\
\text { application of ointment during using; insufficient } \\
\text { pharmacological effect during dosage form using; } \\
\text { loss of consumer properties of ointment, patient's } \\
\text { refusal to purchase such dosage form }\end{array}$ & $\begin{array}{l}\text { Checking the prescription before dosage } \\
\text { form preparation. Manufacturing under } \\
\text { the supervision of the responsible person. }\end{array}$ \\
\hline $\begin{array}{l}\text { Violation of requirements for } \\
\text { personal hygiene rules }\end{array}$ & $\begin{array}{l}\text { Ointment contamination with impurities of other } \\
\text { substances; microbial contamination }\end{array}$ & $\begin{array}{l}\text { Compliance with the requirements for } \\
\text { personal hygiene by persons involved in } \\
\text { the dosage form preparation. Verification } \\
\text { of the prescription before preparation, } \\
\text { manufacturing under the supervision of } \\
\text { the responsible person. }\end{array}$ \\
\hline
\end{tabular}




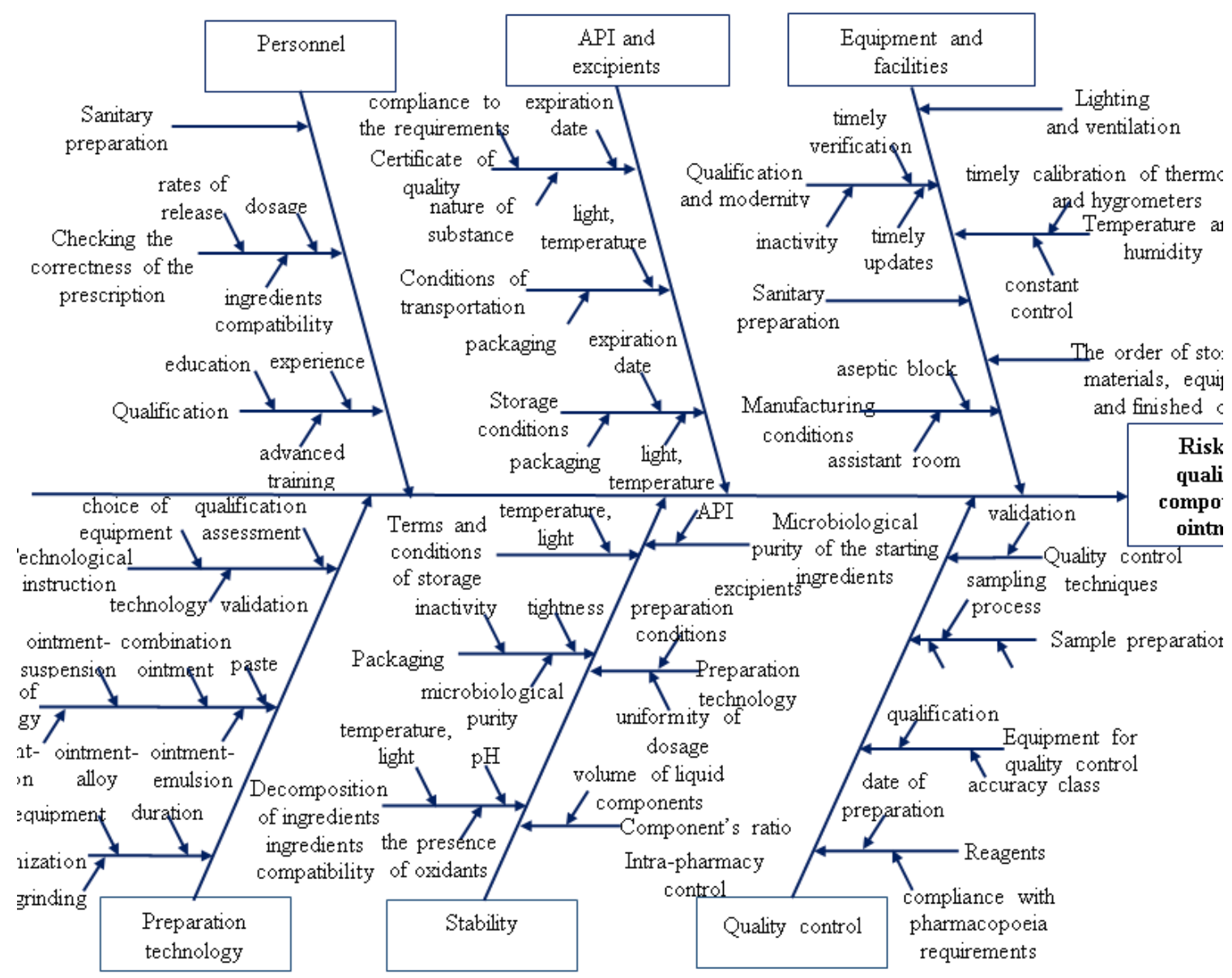

Figure 2.

Diagram of cause-and-effect relationships for the risks for quality of compounding ointments (Ishikawa diagram)

API and excipients. According to the requirements of the SPhU, EurPh and USP $[8,11,12,17]$, for the ointment's preparation active substances and excipients, which meet the requirements of the relevant pharmacopoeia monographs, and in case of their absence - the requirements of the general monograph "Substances for pharmaceutical use", applicable regulations or other requirements (in exceptional cases) should be used. Pharmacopoeia compliance guarantees the quality of the components and reduces the risks for quality of the finished ointment. Compounding ingredients should be purchased from reliable sources. Of course, transportation in the factory packaging is necessary for keeping the quality too.

The quality of API and excipients is the source of several risks for the quality of the finished compounding ointment (Table II).

Appropriate incoming control with verification of supporting documents, invoices, manufacturer's quality certificates, registration status data, compliance of the components with the requirements of the abovementioned documents on visual and organoleptic characteristics is a way to eliminate some possible quality defects.

It is important to keep the proper storage conditions for APIs and excipients in the pharmacy. The use of the factory packaging guarantees the preservation of their quality. Clean glass containers are allowed to use also. The peculiarity of ointments and, accordingly, a critical risk factor for their quality is using of various bases and fatty oils (sunflower, peach, apricot, etc.) for their preparation. The guarantee of the basis's quality preservation during their storage in the glass containers is the conducted stability studies for a certain period and conditions. During fatty oils using, it is important to consider the storage conditions (light access, temperature) and their shelf life at the pharmacy. For the ointment's preparation, it is advisable to use base components and fatty oils as fresh as possible to prevent their negative effect on the ointment quality. Both the SPhU [12] and the USP [17] do not prohibit using of the industrial production medicines in compounding process. In the case of their using, it is necessary to consider the presence of the certificate of analysis, the shelf-life of the medicine, the compatibility of its ingredients with other components of compounding ointment. In case of incomplete use of the industrial production ointment, its storage in the pharmacy and subsequent re-use for the preparation of another compounding ointment is prohibited. 
Potential risk sources for quality of compounding ointments associated with API and excipients

\begin{tabular}{|c|c|c|}
\hline $\begin{array}{c}\text { Potential sources of } \\
\text { quality defects }\end{array}$ & The consequence of the potential defect & Proposed actions for risk mitigation \\
\hline $\begin{array}{l}\text { Discrepancy between } \\
\text { the actual quantitative } \\
\text { content of the active } \\
\text { ingredient in the substance }\end{array}$ & $\begin{array}{l}\text { Overdose (in case of excess content) or insufficient } \\
\text { pharmacological effect (in case of lower content) } \\
\text { during ointment application }\end{array}$ & $\begin{array}{l}\text { Using only registered or approved substances } \\
\text { for the preparation of the dosage forms. Input } \\
\text { quality control of API and excipients. Verification } \\
\text { of accompanying documents }\end{array}$ \\
\hline $\begin{array}{l}\text { Violation of transportation } \\
\text { conditions (damage to } \\
\text { packaging, incorrect } \\
\text { choice of packaging, } \\
\text { failure to observe } \\
\text { temperature conditions, } \\
\text { access of light) }\end{array}$ & $\begin{array}{l}\text { Possibility of contamination with impurities of } \\
\text { other substances or microbial contamination; } \\
\text { mismatch of the quantitative content of API in the } \\
\text { finished ointment }\end{array}$ & $\begin{array}{l}\text { Adherence to the transportation conditions } \\
\text { indicated on the substances label. Checking the } \\
\text { transportation conditions upon receipt of the } \\
\text { substance in the pharmacy. Incoming quality } \\
\text { control. } \\
\text { Mandatory checking the expiration date of the } \\
\text { substance before the dosage form preparation. }\end{array}$ \\
\hline $\begin{array}{l}\text { APIs and/or excipients } \\
\text { are expired }\end{array}$ & $\begin{array}{l}\text { Incorrect indication of expiry date of the finished } \\
\text { ointment; deviation in the dosage of API ointment } \\
\text { during storage; the occurrence of side effects and } \\
\text { (or) insufficient pharmacological effect during } \\
\text { ointment application }\end{array}$ & $\begin{array}{l}\text { Mandatory checking of substance expiration } \\
\text { date before dosage form preparation. }\end{array}$ \\
\hline $\begin{array}{l}\text { Violation of storage } \\
\text { conditions of APIs and } \\
\text { excipients }\end{array}$ & $\begin{array}{l}\text { Unconformity of the quantitative content of API } \\
\text { in the finished ointment; the pollution of the DF } \\
\text { by impurities of substances that were previously } \\
\text { stored in the glass container during preparation; } \\
\text { occurrence of side effects during ointment } \\
\text { application; insufficient pharmacological effect }\end{array}$ & $\begin{array}{l}\text { Strict adherence to the conditions of substance } \\
\text { storage throughout of its shelf life. Upon } \\
\text { detection of a substance with inappropriate } \\
\text { quality, its disposal. Checking the appearance } \\
\text { of substances before dosage form preparation. }\end{array}$ \\
\hline $\begin{array}{l}\text { Using for the ointment } \\
\text { preparation industrial } \\
\text { production medicines } \\
\text { with quality defects or } \\
\text { previously opened }\end{array}$ & $\begin{array}{l}\text { Unconformity of the quantitative content of API } \\
\text { in the finished ointment; penetration of impurities } \\
\text { of other substances into the finished ointment; } \\
\text { occurrence of side effects during ointment } \\
\text { application; insufficient pharmacological effect }\end{array}$ & $\begin{array}{l}\text { Control of medicines for appearance; the first } \\
\text { opening during input control; and before dosage } \\
\text { form preparation }\end{array}$ \\
\hline $\begin{array}{l}\text { Lack of information on } \\
\text { the preservation keeping } \\
\text { quality of ointment } \\
\text { excipients during their } \\
\text { storage in the glass } \\
\text { containers }\end{array}$ & $\begin{array}{l}\text { Unconformity of the ointment quality parameters } \\
\text { during storage period; microbial contamination of } \\
\text { ointment; occurrence of side effects during } \\
\text { ointment application }\end{array}$ & $\begin{array}{l}\text { Carrying out the input quality control of } \\
\text { substances is mandatory. Search for information } \\
\text { in the scientific literature about the study of the } \\
\text { shelf life of these substances. Verification of the } \\
\text { requirements specified in the substance quality } \\
\text { certificate. }\end{array}$ \\
\hline $\begin{array}{l}\text { No pharmacopoeial } \\
\text { articles regulating the } \\
\text { quality control of fatty } \\
\text { oils or ointment bases }\end{array}$ & $\begin{array}{l}\text { Unconformity of the ointment quality parameters } \\
\text { during storage period; occurrence of side effects } \\
\text { during ointment application }\end{array}$ & $\begin{array}{l}\text { Carrying out the input quality control of substances } \\
\text { is mandatory. Search for information in the } \\
\text { scientific literature about the study of the shelf } \\
\text { life of these substances. Verification of the } \\
\text { requirements specified in the substance quality } \\
\text { certificate. }\end{array}$ \\
\hline
\end{tabular}

Equipment and facilities. According to the requirements $[15,17]$, compounding facilities should be tailored to these activities to minimize the risk of quality defects (Table III). The risk for the ointment's quality is the possibility of contamination by components that may be stored improperly or by mix-up during dispensing or measuring the components. Therefore, the placement and use of equipment should be organize so to minimize the risk of errors $[15,17]$. To prevent contamination of ointments during preparation and for proper air purification, rooms should be equipped with inflow and exhaust ventilation. The facilities should have adequate lighting to prevent errors during medicines preparation (errors in calculations, incorrect dosing or measuring of ingredients etc.).

To preservation the quality of the ointment components and the finished compounding ointments, providing the appropriate temperature and humidity, which should be timely controlled, is important. To prevent the deterioration of quality of the ointments or their components, thermometers and hygrometers should be timely calibrated.

Equipment also has the direct influence on quality of the compounding ointments. The task of the head of the compounding pharmacy is to ensure the correctness and accuracy of all measuring instruments by regular metrological verification in accordance with the legislation [15]. In addition, the equipment has to be updated in a timely manner to prevent deviations in dosing or measuring of components.

The risk for quality of the finished ointments may be due to inadequate cleaning of the compounding facilities and equipment. As a consequence, the finished compounding ointment might be contaminated with 
FARMACIA, 2021, Vol. 69, 4

impurities from other substances used in the preparation of previous dosage form or by microorganisms. Therefore, it is important to check the compliance with the requirements for the sanitary processing of facilities and equipment before starting the preparation of every next ointment.

Table III

Potential risk sources for quality of compounding ointments associated with equipment and facilities

\begin{tabular}{|l|l|l|}
\hline \multicolumn{1}{|c|}{$\begin{array}{c}\text { Potential sources of } \\
\text { quality defects }\end{array}$} & \multicolumn{1}{|c|}{ The consequence of the potential defect } & \multicolumn{1}{|c|}{ Proposed actions for risk mitigation } \\
\hline $\begin{array}{l}\text { Using of an equipment } \\
\text { which doesn't suit for } \\
\text { dosage form preparation }\end{array}$ & $\begin{array}{l}\text { Preparation of dosage form with deviations in the } \\
\text { quantitative content of API, excipients and in the } \\
\text { total mass }\end{array}$ & $\begin{array}{l}\text { Analysis of the prescription before preparation, } \\
\text { choosing of equipment and its inspection by } \\
\text { the responsible person }\end{array}$ \\
\hline $\begin{array}{l}\text { Absence of inflow and } \\
\text { exhaust ventilation }\end{array}$ & $\begin{array}{l}\text { Microbiological and other contamination of the } \\
\text { dosage forms }\end{array}$ & $\begin{array}{l}\text { Mandatory installation of inflow and exhaust } \\
\text { ventilation during the pharmacy building }\end{array}$ \\
\hline Insufficient lighting & $\begin{array}{l}\text { Errors in calculation of quantitative content of dosage } \\
\text { form components; the possibility of errors in choosing } \\
\text { the necessary component during the dosage form } \\
\text { preparation; incorrect measuring and dosing of the } \\
\text { components }\end{array}$ & $\begin{array}{l}\text { Timely providing the facilities for the } \\
\text { lighting }\end{array}$ \\
\hline $\begin{array}{l}\text { Using of non-calibration preparation by the necessary } \\
\text { thermometers and } \\
\text { hygrometers }\end{array}$ & $\begin{array}{l}\text { Possible deterioration of conditions of storage and } \\
\text { preparation of ointments in facilities is possible. } \\
\text { Deterioration of the components of ointments and } \\
\text { finished ointments (absorption of water from the } \\
\text { air, change in the consistency of the ointment, etc.). }\end{array}$ & $\begin{array}{l}\text { Timely calibration of thermometers and } \\
\text { hygrometers }\end{array}$ \\
\hline $\begin{array}{l}\text { Using of non-calibrated } \\
\text { equipment for weighing } \\
\text { and measuring of } \\
\text { ointment ingredients } \\
\text { during its preparation }\end{array}$ & $\begin{array}{l}\text { Preparation of ointments with incorrect API and } \\
\text { excipients dosage, deviations in the total mass of } \\
\text { ointments. Insufficient pharmacological effect } \\
\text { during ointment application. }\end{array}$ & Timely calibration of equipment \\
\hline
\end{tabular}

Preparation technology. The technology of ointment preparation is determined by the pharmacist after receiving the prescription. The correctness of its choice depends on his proficiency. However, using some approaches, the risks associated with ointment technology (Table IV) can be minimized.

Table IV

Potential sources of risk for quality of compounding ointments related to their manufacturing technology

\begin{tabular}{|c|c|c|}
\hline $\begin{array}{l}\text { Potential sources of quality } \\
\text { defects }\end{array}$ & The consequence of the potential defect & Proposed actions for risk mitigation \\
\hline \begin{tabular}{|l} 
The wrong choice of \\
technology for the \\
preparation of ointment \\
depending on its nature
\end{tabular} & $\begin{array}{l}\text { Mismatch of physical properties of ointment } \\
\text { during storage period (appearance of visible } \\
\text { solids, delamination); mismatch uniformity of } \\
\text { ointment dosage; loss of consumer properties of } \\
\text { the ointment, patient's refusal to purchase such } \\
\text { dosage form; harm to the patient's health } \\
\text { (insufficient pharmacological effect or overdose } \\
\text { during ointment application) }\end{array}$ & $\begin{array}{l}\text { Analysis of the prescription and choosing of } \\
\text { the technology before the dosage form } \\
\text { preparation. The revision by the responsible } \\
\text { person. Manufacturing under the supervision } \\
\text { of the responsible person. }\end{array}$ \\
\hline $\begin{array}{l}\text { Excessive losses of rubbing } \\
\text { solids in the pores of the } \\
\text { mortar }\end{array}$ & $\begin{array}{l}\text { Insufficient pharmacological effect during } \\
\text { ointment application }\end{array}$ & $\begin{array}{l}\text { Timely updating of the mortars; choosing } \\
\text { mortars for the dosage form preparation } \\
\text { according with its number }\end{array}$ \\
\hline $\begin{array}{l}\text { During selecting of equipment } \\
\text { for the manufacture of } \\
\text { ointment (for weighing and } \\
\text { measuring the ingredients), } \\
\text { its maximum error was not } \\
\text { taken into account }\end{array}$ & $\begin{array}{l}\text { Mismatch of quantitative content of API in } \\
\text { ointment; overdose or insufficient pharmacological } \\
\text { effect during ointment application }\end{array}$ & $\begin{array}{l}\text { Taking into account the error of the equipment } \\
\text { before the dosage form preparation (choice of } \\
\text { scales depending on the optimal load, } \\
\text { deviation of measuring cylinders, etc.) }\end{array}$ \\
\hline $\begin{array}{l}\text { Wrong choice of } \\
\text { homogenization mode or } \\
\text { time of mixing of ointment } \\
\text { in the mortar }\end{array}$ & $\begin{array}{l}\text { Violation of uniformity of dosage of the } \\
\text { finished product; side effects during such } \\
\text { ointment using, overdose or insufficient } \\
\text { pharmacological effect }\end{array}$ & $\begin{array}{l}\text { Organoleptic control during the process of } \\
\text { ointment preparation by the responsible } \\
\text { person }\end{array}$ \\
\hline $\begin{array}{l}\text { Incorrect ratio of ointment } \\
\text { components (excess of } \\
\text { liquid components) }\end{array}$ & $\begin{array}{l}\text { Mismatch of ointment rheological parameters; } \\
\text { loss of uniformity of application of ointment } \\
\text { and accuracy of dosing of API; insufficient } \\
\text { pharmacological effect and/or side effects during } \\
\text { ointment application }\end{array}$ & $\begin{array}{l}\text { Checking the prescription before preparation } \\
\text { for the ratio of solid and liquid components. } \\
\text { Checking the prescription by the responsible } \\
\text { person. Manufacturing under the supervision } \\
\text { of the responsible person. }\end{array}$ \\
\hline
\end{tabular}


First of all, when choosing a technology, the pharmacist should take into account the type of ointment (ointmentsuspension, ointment-solution, ointment-alloy, ointmentemulsion, paste or combination ointment), since each of them has its own technology features that ensure the quality of the finished product. Apart from the preparation technology itself, it is important to choose the correct compounding equipment.

In order to prevent equipment selection errors, the validation of the preparation technology should be done prior to the preparation of the semisolid dosage form (for specific ointment with specific equipment). This will take into account the permissible error of the equipment for a particular ointment. Especially important may be the role of the validation of technology for the preparation of extemporaneous ointments. Quality control of such ointments is optional and is not generally carried out, so validation of the technology will guarantee the quality of the finished medicine. This approach is an element of the Quality by design system, when critical factors are considered during the

process of ointment manufacturing, which ensures an appropriate level of quality of the finished product. The guarantee of quality of ointments which are made for stock (pharmaceutical preparations prepared in advance and stored until a request) is their preparation according to the preliminary developed and approved in the established order technological instructions. Technological instruction is developed for a specific pharmacy and dosage form with description of the specific equipment that can be used for the preparation process. Technological instructions should be subject to a qualification assessment, followed by an examination of the quality of the finished ointment using the preparation process described.

Stability. Factors that are the sources of potential defects in ointment quality due to stability include: the possible decomposition of API; the ratio of ointment components (quantity of liquids and ointment base); the choice of preparation technology; microbial contamination of the starting ointment ingredients, equipment and primary packaging; the correct indication of expiration date and conditions of storage (Table V).

Table V

Potential sources of stability-related risk for quality of compounding ointments

\begin{tabular}{|c|c|c|}
\hline $\begin{array}{l}\text { Potential sources of quality } \\
\text { defects }\end{array}$ & The consequence of the potential defect & Proposed actions for risk mitigation \\
\hline $\begin{array}{l}\text { Decomposition of ointment } \\
\text { ingredients during storage } \\
\text { period }\end{array}$ & $\begin{array}{l}\text { Changing of physical properties of the ointment; } \\
\text { reducing the quantitative content of API during storage } \\
\text { period; the appearance of impurities in the composition } \\
\text { of the ointment during storage period; insufficient } \\
\text { pharmacological effect and/or side effects during } \\
\text { ointment application }\end{array}$ & $\begin{array}{l}\text { Check-up the shelf life of ointment } \\
\text { components throughout the specified } \\
\text { storage time. Inspection of all } \\
\text { components of the ointment for } \\
\text { quality preservation before using }\end{array}$ \\
\hline $\begin{array}{l}\text { Microbial contamination of } \\
\text { start ingredients, packaging, } \\
\text { and compounding equipment }\end{array}$ & $\begin{array}{l}\text { Increasing the microbial contamination of ointment } \\
\text { during the storage; adverse effect on the patient's } \\
\text { health, reducing or inactivating the therapeutic effect } \\
\text { of the ointment }\end{array}$ & $\begin{array}{l}\text { Proper storage of packaging and } \\
\text { equipment; storage of the } \\
\text { components in tightly closed } \\
\text { containers. }\end{array}$ \\
\hline $\begin{array}{l}\text { Incorrect indication of } \\
\text { expiration date and storage } \\
\text { conditions }\end{array}$ & $\begin{array}{l}\text { The appearance of impurities in the ointment during } \\
\text { storage period; microbial contamination; insufficient } \\
\text { pharmacological effect and/or side effects during } \\
\text { ointment application }\end{array}$ & $\begin{array}{l}\text { Indication of terms and storage } \\
\text { conditions according to the } \\
\text { requirements of regulatory framework } \\
\text { taking into account properties of the } \\
\text { ointment components }\end{array}$ \\
\hline $\begin{array}{l}\text { Non-sealed or inappropriate } \\
\text { primary packaging of the } \\
\text { ointment }\end{array}$ & $\begin{array}{l}\text { The appearance of impurities in the ointment during } \\
\text { storage period; delamination of the ointment; microbial } \\
\text { contamination; insufficient pharmacological effect } \\
\text { and/or side effects during ointment application }\end{array}$ & $\begin{array}{l}\text { The choice of packaging according to } \\
\text { the ointment components properties. } \\
\text { Control during the medicine release. }\end{array}$ \\
\hline
\end{tabular}

According to the SPhU requirements [12], the maximum expiration date of compounding dosage form, including ointments, is 10 days. The extension of the shelf-life is possible in the presence of studies on the stability of the ointment during storage under certain conditions in the selected package. It is mandatory for such studies to control the quantitative content of ointment API, appearance of possible impurities, preservation of uniformity of dosage, preservation of physical properties, compliance with the parameters of microbiological purity, taking into account the conditions of storage of the ointment and its packaging. The inclusion of oily solutions of vitamins, fatty oils, etc. into the ointment, is an additional risk factor for microbial contamination, so special attention should be paid to the permissible shelf life of such ointments.

The loss of the ointment stability is primarily indicated by the presence of any physical changes (discoloration, the appearance of odours, signs of delamination, the presence of visible solids, sweating, etc.). Such ointment cannot be released to the patient.

Quality control. Proper quality throughout lifecycle of the finished extemporal product guarantees the quality, effectiveness and safety of the product for the patient. Appropriate quality of the extemporal dosage forms provided in the pharmacy through the 
FARMACIA, 2021, Vol. 69, 4

implementation and effective functioning of the pharmaceutical quality system.

First of all, quality of the finished ointments ensured by different types of intra-pharmacy quality control. Compliance with the requirements of each of them will ensure timely detection of deviations in ointments quality. Quality control is important for stock ointment too. One of the subdivisions of the technological instruction for the preparation of such dosage form is the methods of their quality control. Pharmacopoeial techniques should be primarily used to ensure the correctness of the quantitative determination of ointments API. If any changes were made, they must be verified. Other techniques are allowed, but they should be validated beforehand.

Another important step in quality control and, at the same time, a risk factor is sample handling. Feature of ointments is the need to separate the API from the ointment base before conducting of the analysis. In order to obtain correct conclusions about the quality of the ointment, it is important to ensure the completeness of extraction due to the optimal selection of solvents, taking into account the properties of API. In addition, attention should be paid to the possible loss of API during the solution filtering. If it is possible to directly dissolution of the ointment base in the solvent with subsequent analysis performing, such scheme should be the subject of choice. In order to ensure proper level of the API uniformity of the dosage during the ointment storage, the sampling process should be clearly described.

Another factor that can affect the correctness of the conclusion about the quality of the finished compounding ointment is the equipment used for analysis. Only equipment that meets the requirements of pharmacopoeia and class A glassware should be used for proper quality control. The equipment should be properly qualified on time.

The last risk factor for quality control of the ointments is the reagents used for this purpose. To prevent errors and incorrect conclusions about the quality of the ointment, it is necessary to clearly monitor the date of the reagents preparation and use only those reagents that meet the pharmacopoeial requirements.

\section{Conclusions}

Identification of risks for the quality of compounding ointments by using the Ishikawa diagram construction has done. Six main categories that can affect their quality were defined: personnel; APIs and excipients; facilities and equipment; preparation technology; stability and quality control.

For each of these categories, the causes of possible appearance of defects for the quality of compounding ointments have been identified. Their consideration will allow obtaining the product of the appropriate quality. The obtained results will be used in the next step of research - quantitative assessment of risks for the quality of compounding ointments.

As the requirements of the regulatory framework for the preparation of ointments in pharmacies in Ukraine, EU and the USA are very similar, the obtained results on the identification of risks for quality of compounding ointments can be used for the implementation of quality assurance system in compounding pharmacies in different countries.

\section{Conflict of interest}

The authors declare no conflict of interest.

\section{References}

1. Allen LV Jr, Basics of compounding: implementing United States Pharmacopeia chapter <1163> Quality assurance in pharmaceutical compounding. Part 1. Int J Pharm Compd., 2012; 16(2): 146-150.

2. Allen LV Jr, Basics of compounding: implementing United States Pharmacopeia chapter <1163> Quality assurance in pharmaceutical compounding. Part 2: Documentation and verification. Int J Pharm Compd., 2012; 16(3): 230-234

3. Allen LV Jr, Basics of compounding: implementing United States Pharmacopeia chapter <1163> Quality assurance in pharmaceutical compounding. Part 3: Testing. Int J Pharm Compd., 2012; 16(4): 322-328.

4. Allen LV Jr, Basics of compounding: implementing United States Pharmacopeia chapter $<1163>$ Quality assurance in pharmaceutical compounding. Part 4: Cleaning and packaging. Int J Pharm Compd., 2012; 16(5): 405-414.

5. Allen LV Jr, Basics of compounding: implementing United States Pharmacopeia chapter <1163> Quality assurance in pharmaceutical compounding. Part 5: Outsourcing and responsible personnel. Int J Pharm Compd., 2012; 16(6): 490-496.

6. European Medicines Agency, ICH guideline Q10 on pharmaceutical quality system, 2015; www.ema.europa. $\mathrm{eu} / \mathrm{en} /$ documents/scientific-guideline/internationalconference-harmonisation-technical-requirementsregistration-pharmaceuticals-human_en.pdf.

7. European Medicines Agency, ICH guideline Q9 on quality risk management, 2015; www.ema.europa. eu/en/documents/scientific-guideline/internationalconference-harmonisation-technical-requirementsregistration-pharmaceuticals-human-use_en-3.pdf.

8. European Pharmocopoeia,10.5 ${ }^{\text {th }}$ ed. European Directorate for the Quality of Medicines \& Health Care of the Council of Europe, Strasbourg, 2021.

9. International Electrotechnical Commission, IEC/ISO 31010:2019: Risk management - Risk assessment techniques. Geneva, 2019; www.iso.org/standard/ 72140.html.

10. Locwin $\mathrm{B}$, When to use a fishbone diagram and why you should do it more often than you think. Pharmaceutical online, 2018; www.pharmaceuticalonline. $\mathrm{com} /$ doc/when-to-use-a-fishbone-diagram-and-whyyou-should-do-it-more-often-than-you-think-0001.

11. State Pharmacopoeia of Ukraine, Vol. $1,2^{\text {nd }}$ ed. Ukrainian scientific pharmacopoeial centre for quality of medicines, Kharkiv, 2015. 
12. State Pharmacopoeia of Ukraine, Vol. $3,2^{\text {nd }}$ ed. Ukrainian scientific pharmacopoeial centre for quality of medicines, Kharkiv, 2014.

13. The Ministry of Health of Ukraine, Guideline ST-N MOHU 42-4.5:2015: Requirements for the preparation of non-sterile medicines in pharmacies, https://gmpua. com/World/Ukraine/3nesterilnix.pdf., (available in Ukrainian).

14. The Ministry of Health of Ukraine, Guideline ST-N MOHU 42-4.6:2015: Requirements for the preparation of sterile medicines in pharmacies, (available in Ukrainian).

15. The Ministry of Health of Ukraine, Order No 812 "About the approval of production (compounding) rules and quality control of preparations in pharmacies". Official Bulletin of Ukraine, 2012; 87: 166, (available in Ukrainian).
16. Timko RJ, Applying quality by design concepts to pharmacy compounding. Int J Pharm Compd., 2015; 19(6): 453-463.

17. USP compounding: A Guide for the Compounding Practitioner. US Pharmacopoeial Convention, Rockville, 2012.

18. Yevtifeeva OA, Analytical review of the quality assurance system of extemporaneous medicines in the world developed countries. News of Pharmacy, 2013; 1(73): 9-18.

19. Zdoryk OA, Organization of the quality assurance system of compounding pharmacies in Ukraine: results of the survey. News of Pharmacy, 2014; 4(80): 64-68.

20. Zdoryk OA, Quality assurance strategy of pharmacy compounded drugs. Pharmaceutical Journal, 2019; 2: 66-72. 